\title{
Yeni Medya İletişim Kanalı Olarak Katılımcı Sözlük Sitelerine Yönelik Bir Değerlendirme
}

\author{
DOI: 10.26466/opus.567125
}

\section{Engin Üngüren*}

\author{
Dr. Öğr. Üyesi, Alanya Alaaddin Keykubat Üniversitesi, İşletme Fakültesi, Alanya/ \\ Antalya/Türkiye \\ E-Posta: enginunguren@gmail.com \\ ORCID:0000-0002-7223-2543
}

\section{Öz}

Bilişim endüstrisinde bir devrim olarak ifade edilen web 2.0, kullanıcılarının, fotoğraf, video, müzik yükleyebileceği, yorum yapabileceği, deneyimlerini diğer kişilerle paylaşabileceğii, bir başka deyişle sitenin içeriğini doğrudan etkileyebildiği internet siteleridir. Web 2.0'nin temel uygulamaları arasında, wiki, bloglar, sosyal paylaşım ağları, topluluk siteleri, forum siteleri yer almaktadır. Makale kapsamında ele alınan katılımcı sözlük siteleri, Web 2.0 kapsamında değerlendirilmekte ve her türlü kişi, kelime, olay, durum ve kavram hakkında, kayıtlı yazarlarm yorumların içeren ve subjektif sunumlarıyla genişletilen ă̆ sayfaları olarak tanımlanmaktadır. Katılımo sözlük siteleri, Türkiye'de en çok ziyaret edilen web sayfaları arasında yer almaktadır. Doğrunun ne olduğuna ilişkin kalıpların sorgulanmasına aracılık eden ve kendiliğinden düzen esasına göre işleyen sanal bir oluşum olan katılımcı sözlük siteleri, çağdaş dünyaya özgü bir iletişim biçimini tanımlaması ve kamuoyu oluşturması bakımından önem teşkil etmektedir. Çalışmanın katılımoı sözlük sitelerini konu edinmesinin temel gerekçesi, bu tür sitelerin kamuoyu oluşturma ve bilgilendirme konusunda önemli bir mecra haline gelmesidir. Bu çerçevede makalede Web 2 olarak değerlendirilen katılımcı sözlük sitelerinin ülkemizdeki gelişimi ortaya konmuş, kullanıcı profili ve temel motivasyon faktörleri incelenmiş ve katılımcı sözlük sitelerine yönelik eleştirel söylemler ele alınarak katılımcı sözlük sitelerinin genel bir değerlendirmesi yapılmıştır.

Anahtar Kelimeler: Yeni medya, Katılımcı sözlük siteleri, web 2, internet, etkileşim 


\title{
A Review of Collaborative Hypertext Dictionary as a New Media Communication Channel
}

\begin{abstract}
Web 2.0, which is expressed as a revolution in the information industry, is a web site where users can upload photos, videos, music, comment, share their experiences with others, or influence the content of the site. Among the basic applications of Web 2.0, wiki, blogs, social networks, community sites, forum sites are located. The collaborative hypertext dictionary sites, which are evaluated within the scope of the article are evaluated within the scope of Web 2.0 and are defined as network pages that contain comments from registered authors about all kinds of people, words, events, situations and concepts and expanded with subjective presentations. The collaborative hypertext dictionary sites are among the most visited web pages in Turkey. The collaborative hypertext dictionary sites, a virtual entity that mediates the questioning of patterns of truth and works on a self-order basis, are important in terms of defining a form of communication specific to the contemporary world and creating a public opinion. The main rationale for the study to be the subject of collaborative hypertext dictionary sites is that such sites to become an important channel for public opinion creation and information. In this paper, the development of collaborative hypertext dictionary sites in Turkey has been revealed, the user profile and basic motivation factors have been examined and critical discourses for that sites have been discussed and an overview of collaborative hypertext dictionary sites has been made.
\end{abstract}

Keywords: New media, collaborative hypertext dictionary sites, Web 2, internet, interaction. 


\section{Giriş}

2000'li yılların başından itibaren, donanım, yazılım ve teknik olarak ağ altyapısının gelişmesi, internette yeni bir paradigmanın doğmasına neden olmuştur. Web 2.0 veya son yıllarda daha moda ismiyle, sosyal medya olarak adlandırılan yeni nesil web siteleri, kullanıcının fotoğraf, video, müzik yükleyebileceği, yorum yapabileceği, deneyimlerini diğer kişilerle paylaşabileceği, bir başka deyişle sitenin içeriğini doğrudan etkileyebileceği bir mecraya dönüşmüştür. Gelecek fikirlerini söyleyen ve yayan insanların olacağını ifade eden Godin (2004), fikirlerin bir virüs gibi yayılmasında internetin lokomotif gücüne vurgu yapmaktadır. İnternetten evvel bir fikir kısıtlı bir alanda ve tek kaynaktan yayılırken, bugün kullanıcı tabanlı içerik oluşturanlar sayesinde ağızdan ağza yayılan ve yayıldıkça yenilenen, değişen, tekrar düzenlenen fikirler, hem daha fazla sayıda insana ulaşmakta hem de daha nitelikli bilgilerin doğmasına yol açmaktadır (Akt. İşlek, 2012, s12-13).

$\mathrm{Bu}$ açıklamalardan da anlaşılacağı üzere internetin en önemli fonksiyonlarından biri bilgi aktarım aracı olmasıdır. Yani bilgi aktarımı internet aracılığıyla çok farklı boyutlarda kendisini göstermektedir. Arama motorları aracılığıyla sınırsız bilgiye ulaşmak mümkün olmuştur. Bunun yanı sıra, internetin iletişim üzerinde önemli bir etkisi olmuştur. Mekân ve zaman kavramlarını yok sayan internet, çok uzak coğrafyalarda yer alan bireylerle de karşılıklı iletişimi mümkün kılmıştır. Ülkemizde de bilgiyi farklı şekilde aktaran siteler bulunmaktadır. Bunlar arasında en önemlilerinden ve de ülkemizde en çok ziyaret edilen internet sayfaları arasında yer alan katılımcı sözlük siteleri oluşturmaktadır (Yıldırım ve Başer, 2016, s.174-180).

Katılımcı sözlük siteleri web 2.0 döneminin ve sosyal medyanın ilk örneklerinden biri olarak kabul edilmektedir (Susar ve Narin, 2011, s.3). Katılımcı sözlük siteleri sözlükten esinlenilerek oluşturulmuş ve etkileşime dayanan bir web 2.0 projesidir. Katılımcı sözlük siteleri, bilgiyi farklı şekillerde aktaran bir oluşum olarak karşımıza çıkmaktadır. Katılımcı sözlüklerde, üyeler çeşitli kavramlar hakkında yorumlar yazmaktadır. Bu çeşit oluşumlarda her bir üye oluşuma yazarak katkıda bulunduğundan yazar olarak isimlendirilir. Katılımcı sözlüklerde üye olan yazarlar "entry" olarak isimlendirilen, kavram, olay, kişilerle ilgili başlık açarak yorum ve 
açıklama yapabilmekte ve bu başlıklara diğer kullanıcılar da yorum yaparak çok geniş içerik yapısına sahip olabilmektedir. Bu sözlükler bir anlamda internet forumlarının vasıf değiştirmiş şekilleridir. Sözlüklerin internet forumlardan farkları, forumların belirli bir konuya özgü, kısıtland1rılmış konular içermesidir. Katılımcı sözlük sitelerinde ise, bir konu kısıtlaması söz konusu değildir. Sözlüklerde objektif bilgiler kadar, sübjektif bilgi ve görüssler de yer almaktadır. Katılımcı sözlük sitelerinde yazarlar kendi görüşlerini ortaya koymakla birlikte; ortaya koyduğu görüşlerin doğru olma zorunluluğu bulunmamaktadır. Bu açından da bakıldığında katılımcı sözlük siteleri, internet ansiklopedilerinden farklı doğrusal bilgi içerme zorunluluğu olmamasından dolayı farklılaşmaktadır. Haliyle katılımcı sözlüklerde, bir konu hakkında çok çeşitli bilgiler bulunmaktadır. Bu bilgiler, objektif ve doğru olabildiği gibi manipüle edici de olabilmekte, ilgili konu hakkında olumsuz düşünceleri de içerebilmektedir (Yıldırım ve Başer, 2016,s.186; Akkılıç, 2018, s.19; Lüküslü, 2011,s.52).

Katılımcı sözlük sitelerinin Türkiye'deki ilk örneği Sedat Kapanoğlu tarafından, Şubat 1999 tarihinde kurulan Ekşi Sözlük'tür (Akyazı 2014, s.188). Ekşi Sözlük kurulduktan sonra Ekşi Sözlük formatını aynen klonlayarak kurulan birçok farklı katılımcı sözlük sitesi kurulmuştur. Kuruldukları tarihten itibaren her zaman popüler olan ve ülkemizde günlük olarak en fazla ziyaretçi sayısına ulaşan katılımcı sözlük siteleri, gündeme dair her şeyi halktan kişilerin yorumlamasına olanak tanıması bakımından dikkat çekmektedir. Doğrunun ne olduğuna ilişkin kalıpların sorgulanmasına aracılık eden ve kendiliğinden düzen esasına göre işleyen sanal bir oluşum olan katılımcı sözlük siteleri, çağdaş dünyaya özgü bir iletişim biçimini tanımlaması ve toplumda kamuoyu oluşturması bakımından önem teşkil etmektedir (Sine ve Özsoy, 2017, s.54). Armağan ve Deniz'in (2012) de belirttiği gibi pek çok siyasetçi, sanatçı, medya mensubu ve akademisyen, tartışmalı konularda kamuoyunun ne yönde olduğunu tespit edebilmek için katılımcı sözlük sitelerini baz alabilmektedir.

Katılımcı sözlüklerin artan popülaritesi onu akademik araştırmaların önemli bir konusu haline getirmeye başlamıştır. Sözlükler son yirmi yıl içerisinde akademik çalışmalarında ilgi odağ tadır. Katılımcı sözlük üzerine çalışmalar genel olarak söylem ve içerikler üzerine eğilimli olmuştur (Duman ve Özdoyran, 2018, s.84). Çalışmanın 
katılımcı sözlük sitelerini konu edinmesinin temel gerekçesi, bu tür sitelerin kamuoyu oluşturma ve bilgilendirme konusunda önemli bir mecra haline gelmesidir. Bu çerçevede makalede Web 2 olarak değerlendirilen katılımcı sözlük sitelerinin ülkemizdeki gelişimi ortaya konmuş, kullanıcı profili ve temel motivasyon faktörleri incelenmiş ve katılımcı sözlük sitelerine yönelik eleştirel söylemler ele alınarak katılımcı sözlük sitelerinin genel bir değerlendirmesi yapılmıştır.

\section{Kavramsal Çerçeve}

Web 2.0 kullanıcıların sosyal ve iş süreçlerine, deneyimlerini ve bilgilerini interaktif olarak aktararak katıldıkları, çevrimiçi uygulamaları içeren açık bir kaynak şeklinde tanımlanabilir. Daha farklı bir ifadeyle Web 2.0 uygulamaları bireysel kullanıcıların fikir, bilgi ve deneyimlerini paylaşarak ve yayarak zenginleştirdiği, içeriğini kendilerinin belirlediği bir ağ oluşturmaların destekleyen uygulamalardır (Constantinides ve Fountain, 2008, s.233). En basit haliyle Web 2.0 bir kişinin internette kolaylıkla içerik oluşturabilmesi ve var olan içeriğe katkıda bulunabilmesidir. Web 2.0 uygulamaları internet kullanımını bütünüyle değiştiren bir yapıya sahip olarak ortaya çıkmıştır (Atıcı ve Yıldırım, 2010, s.287).

Web 2.0 kavramı ilk olarak 2004 yılında bilgisayar konusunda kitaplar yayınlayan Tim O'Reilly tarafından gerçekleştirilen "Web 2.0 Konferansı" ile literatüre girmiş ve Wikipedia'nın 2001 yılında kurulmasıyla hayat bulmuştur. İnternet'in ilk yıllarında, bilginin sadece vitrinde sunulması ve bilgi gereksiniminin bu alanlardan sağlanması söz konusuyken; bugün Web 2.0 ile daha etkileşimli, paylaşım odaklı ve ortaklaşa bilgi üretimi ve kullanımı, interneti vazgeçilmez bir mecra haline getirmiştir (Kutlutürk ve Albayrak, 2013).

Web 2.0 ve Web 1.0 arasındaki temel farklılıklar ifade edilecek olursa; Web 2.0'nin ana özelliği, kendi istediğiyle katılan kullanıcıların, bilgiyi paylaşıp güncelleştirebildiği, bireyleri ve örgütleri bir topluluk içinde birbirine bağlayan ağlar kurmasını sağlayan teknolojik altyapıyı sağlamasıdır. Örgütsel bakış açısından, bu durum bilginin demokratikleşmesi anlamına gelmektedir (Jackson ve Lilleker, 2009, s.233). Web 1.0 alt yapisının uygulandığı siteler ulaşan her kullanıcıya bilgi vermektedir. Fakat bu si- 
teler tek taraflıdır. Web 2.0 daha çok kullanıcıların internet üstünden birbirleriyle etkileşimini sağlar (Barsky, 2006,s.33; Sigala, 2009, s1343). Web 1.0 kullanıcının, durağan bir web sitesine ulaşmasını sağlarken, web 2.0 kullanıcının sitenin içeriğine katkı yapmasını sağlayacak araçlar barındırmaktadır. Ayrıca, kullanıcıların, ilgilendikleri web sitelerindeki içerik değişikliklerini, web sitesini ziyaret etmek zorunluluğu olmadan bile, izleyebilecekleri araçlar sunmaktadır. Web 2.0 sadece, bilinen eski Web'in yeni bir versiyonu değil, tamamen yeni bir bakış açısıdır ve bir çok şekilde web 1.0'den tamamen ayrilmaktadır (Murugesan, 2007, s.34). Web 1.0'in ana işlevi ticari örgütlerin kurumsal yapılarını, ürünlerini, fiyatları gibi bilgileri daha geniş bir kitleye ulaştırmak olmuşken, web 2.0 toplumla ilgili her şeyi kapsamaktadır (Barksy ve Purdon, 2006, s.65).

Kullanıcı tarafından oluşturulan içerik ve Web 2.0 insanların bilgiyi arama, bulma, okuma, toplama, paylaşma, geliştirme ve tüketme davranışlarını yüksek oranda değiştirmiş ve gelecekte de değiştirmeye devam edecektir. Çünkü internet, kişilerin kendi bilgi ve düşüncelerini başkalarına aktarmasına izin vermektedir ve buradaki diğer kişiler, kişinin toplumsal hayatta ulaşıp iletişime geçebileceği sayıdan çok daha fazla olma potansiyeli taşımaktadır. İnternetin bu evrimi ve kullanıcı tabanlı içeriğin artan önemi insanların internette daha aktif ve daha üretken olmalarını sağlamaktadır (İşlek, 2012, s10-11). Bu bağlamda Küçükcan (2005,s.215216) interneti, kamusal alanı devlete ait resmi alan olarak değil, farklı birey ve grupların görüşlerini, düşüncelerini ve taleplerini serbestçe dile getirdikleri, temsil edildikleri ve kaynakları eşit oranda sahiplenme ve kullanma amacıyla baskı altında kalmadan rekabete katılmalarına imkan tanıyan bir temsil ve firsat alanı olarak algılanması anlamında yeni bir kamusal alan, siyasal, sosyal değişimlerin ve gelişmelerin bir yansıması olarak ifade etmektedir (Özbolat, 2013, s55).

Web 2.0'nin temel uygulamaları arasında, wiki, bloglar, sosyal paylaşım ağları, topluluk siteleri, forum siteleri yer almaktadır (Constantinides ve Fountain, 2008,s.233; Beldarrain, 2006, s.140). Araştırma kapsamında değerlendirmeye alınan katılımcı sözlük sitelerinde Web 2.0 türlerinden birini oluşturmaktadır. 


\section{Katılımcı Sözlük Siteleri}

Katılımcı sözlük siteleri en basit tanımıyla, sözlükten esinlenilerek oluşturulmuş ve etkileşime dayanan bir internet uygulamasıdır. Detaylı bir ifadeyle katılımcı sözlük siteleri, insanların paylaşmak amacıyla olaylar, kişiler, kavramlar üzerine tanımlamalarda ve yorumlamalarda bulunarak fikirlerini, hissettiklerini yazdıkları interaktif bir sözlüktür (Susar ve Narin, 2011,s.3; Bozkurt ve Biroğul, 2012, s.17). Katılımcı sözlük siteleri, klasik bir sözlükte yer aldığı gibi kelime ve deyimlerin anlamlarını, tanımlarını vermektedir ancak bu anlam ve tanımlar herkesçe kabul edilen genel geçer anlam ve tanımlar değildir. Bunlar, özneldir, tamamen yazarların görüşlerini yansıtmaktadır. Bu nedenle de genel geçer tanımlamaların d1şında, her yazarın o kavramı nasıl algıladığına dair farklı görüşler bulunmaktadır (Armağan ve Deniz, 2012, s.77).

Katılımcı sözlük sitelerinde yazar olan herkes görüşlerini sözlük arac1lığıyla siteyi takip eden herkese duyurabilme imkânına sahiptir. Haliyle Bu sözlüklerde Vikipedi benzeri yapılardan farklı olarak sadece ansiklopedik bilgi girilmemekte yazarlar aynı madde ile ilgili kendi görüşlerini açıklayarak tanımlara katkıda bulunabilmektedir. Bu yapısı nedeniyle katılımcı sözlük sitelerinin farklı değişik görüşlerin ortaya konularak görüş çeşitliliğin sağlanmasına katkıda bulunabilmektedir (Duman ve Özdoyran, 2018, s.84; Uçkan, 2012 ,s.23; Lüküslü, 2011, s.53). İçerikleri kullanıc1lar tarafından oluşturulan, dolayısıyla birer sosyal paylaşım sitesi konumunda bulunan bu sözlüklerde üyeler istedikleri konulardaki düşüncelerini site kurucuları tarafından belirlenen kurallar çerçevesinde yazabilmektedir. Üyelerin "yazar" olarak nitelendirildiği bu sistemde, yazarlar istedikleri konularda başlık açabilmekte, bu başlıklar altında yazılan yazılara ise "entry" (giriş) denilmektedir (Varol ve Tayanç, 2016, s.222).

Kavram sınırlaması olmaksızın, herhangi bir konu, durum ya da kişi ile ilgili bilgi, haber ve yorum niteliği taşıyan ifadeleri içeren katılımcı sözlük siteleri, sitenin üye yazarları tarafından açılan giriş (entry) ve girişlere yapılan yorumlara sürekli bir şekilde gelişmektedir. Katılımcı sözlük siteleri, sisteme üye olan kişilerin "yazar" statüsüyle belirli konulara ilişkin fikir ve görüşlerini beyan etmesi esasına göre işleyen, belirli bir kavram ile sınırlandırılmamış olması, yazarların özgür hareket etmesine olanak tanıması ile forumlardan, ansiklopedik bilginin ötesinde bilgi aktarımına 
izin vermesi, yazarların kişisel yorum ve düşüncelerine açık olması ve görüş çeşitliliğine fırsat vermesi ile de ansiklopedik sözlüklerden farklı bir görünüm arz etmektedir (Gürel ve Yakın, 2007, s.203-205). Ancak bu sitelerde kavram, terim ve kişiler hakkında verilen bilgi ve yapılan yorumlar objektif olmayıp, kişisel değerlendirmeleri içerebilmesi, yazarların gerçek isimleri ile değil takma isimlerle (nickname) yazmaları, yorumların hakaret içermesi, hatalı ve yanlış olması bunları okuyan kişilere yanlış ve taraflı bilgiler verebilmektedir. Aynı zamanda kişiler hakkında yapılan yorumlara, yorumu yapılan kişinin cevap ya da yorum yapma imkanı olmaması, hatalı ya da yanlış bir yorumun düzeltilmesine imkan vermemektedir. Bu durum ise ilgili sitelere olan güveni zedeleyebilmektedir.

Gürel ve Yakın'a (2007) göre katılımcı sözlük sitelerinde yazarların gerçek kimliklerini ortaya koymaksızın rumuz ile yazmaları, gerçek hayatta olduklarından daha rahat ve özgür davranmalarını, toplumsal rol ve statü gibi kısıtlayıcıların etkisinden sıyrılmaları sonucunu doğurmaktadır. Yazarların farklı bir kimlik kullanarak kendilerini reel yaşamda olduğundan daha farklı ve özgür ifade edebilmelerine olanak tanıması, pasif bir tutumun aksine aktif bir tutum sergilemelerine izin vermesi ve kendiliğinden düzen esasına göre işlemesi nedeniyle katılımcı sözlük siteleri "Sanal Dövüş Kulübü" olarak nitelenebilmektedir. Bu bağlamda bu sitelerin yazarları da, gerçek yaşamdaki rol ve statülerinden farklı bir varoluş içinde hareket etmektedirler. Sözlük yazarları rumuzları aracılığıyla reel yaşamdan daha farklı davranabilmekte ve daha özgür bir davranış tarzını benimsemektedirler. Gündelik yaşamda kim oldukları bilinmeksizin sanal kimlikleriyle tanınan ve tıpkı bir köşe yazarı gibi takip edilen pek çok sözlük yazarı bulunmaktadır (Gürel ve Yakın, 2007, s.209-210). Ayrıca kişilerin statüsü ve kimlikleri belli olmadığı için her statüdeki bireyin görüşlerini bulunduğu konuma atfedilmiş kimlikten arınarak ortaya koymaktadır. Örneğin; bir siyaset doçentinin paylaştığı düşünce ile herhangi bir kamu yönetimi ve siyaset bilimi öğrencisinin paylaştığı düşünce aynı başlık altında yer almaktadır. Yazarların statüleri bilinmediği için iki düşünceye de eşit mesafede yaklaşılabilmekte ve ikisinin de doğru olabilme ihtimali üzerine düşünülebilmektedir. Böylelikle kamuoyunda ve kitle iletişim araçlarında rahatlıkla gündeme getirilemeyen ve özgürce tartışılamayan pek çok konu dile getirilerek farklı bakış açıları uyarınca tartışılabilmektedir (Yalçın, 2015, s.81). 
Günümüzde birçok kişi bir şey satın almak istediğinde, bilmediği bir kavramı öğrenmek istediğinde, bir yere gitmek istediğinde, bir kişi, yer ya da konu hakkında bilgi sahibi olmak istediğinde ilk yararlandığı kaynak kuşkusuz internet olmaktadır. İnternetin insanların bilgi ihtiyacını karşılamada edindiği konum tartışmasızdır. Günümüzde herhangi bir konu ile ilgili bilgi ihtiyacı olduğunda, çeşitli anahtar kelimelerle arama motorlarına girilmekte ve taranan bilgiler gözden geçirilerek bir kanıya varılmaktadır. İnternetten sağlanan bilgilere ne kadar güvenilebileceği tartışma konusudur. Ancak bu bilgilerin insanlarda belli bir kanaat oluşturduğu da yadsınamaz. Gerçek yaşamda olduğu gibi, sanal ortamda da dedikodu, söylenti, fısıltı gazetesi gibi informal bilgi kaynakları vardır. Bu kaynaklardan birini de katılımcı sözlük siteleri oluşturmaktadır. Bu tür sitelerin özelliği, çok geniş bir yazar grubu tarafından hazırlanması ve bilgilerin doğruluğu ya da yanlışlı̆g gibi bir kaygı güdülmemesidir. Sitenin bu güvensiz özelliğine rağmen, icra ettiği fonksiyon dikkate alındığında, herhangi bir olayla ilgili insanların algılamalarını göstermesi açısından da ilginçtir. Ayrıca bir kavram ya da kişi ile ilgili bilgi almak isteyenlerin başvuru kaynağ sözlük siteleri informal bir bilgi kaynağı olarak düşünülebilir (Erdem ve Bardak, 2010, s.106).

Katılımcı sözlük siteleri, interaktif ve özgün içeriğe imkân veren yapısıyla ve gündelik yaşama dair her şeyin tartışılabildiği ve eleştirilebildiği bir ortam olmasının da etkileriyle diğer sosyal medya sitelerinden ayrılmış ve Türkiye'nin en çok ziyaret edilen web sitelerinden biri olmuştur (https://www.alexa.com/siteinfo/eksisozluk.com-2019; Taşdemir ve Çelik, 2013,s.30). Katılımcı sözlük sitelerinde yoğunluklu olarak, gündemdeki toplumsal ve siyasal sorunlar ele alınarak tartışılmaktadır. Kamusal bir tartışma platformu niteliği taşıması nedeniyle, bu sözlüklerde yer alan girişlerin okur kitlesi üzerinde etkili olacağı açıktır (Varol ve Tayanç, 2016,s. 223). Günümüzde insanlar internet ortamında ortaya çıkan bilgilerden önemli derecede etkilenmektedirler. Bu yönüyle katılımcı sözlük sitelerinin insanlar için resmi bir değeri olmayan ancak kanaat oluşturmada önemli bir fonksiyon icra ettikleri söylenebilir (Erdem ve Bardak, 2010,s.106). Bu yönü katılımcı sözlükler kamuoyu oluşturabilme gücünü göstermektedir (Armağan ve Deniz, 2012, s.77). 


\section{Katılımcı Sözlük Türleri}

Sözlük siteleri, "Genel Etkileşimli Sözlükler”, "Tematik Etkileşimli Sözlükler" ve "Üniversite Sözlükleri" olarak üç başlık altında toplanmaktadır. Genel Etkileşimli Sözlükler (ekşi, inci sözlük vb.) hemen her konuda başlık açllarak yazarların subjektif görüş bildirdikleri yazılardan oluşmaktadır. Tematik Etkileşimli Sözlükler ise belli bir alana odaklanarak alandaki konular üzerine görüş bildirilen yalnızca belli bir alan odaklanmış ve konu sınırlaması bulunan içerikten oluşmaktadır. Sportif Sözlük, Siyasi Sözlük, Deniz Sözlük, Sinema Sözlük bu kategorinin bilinen örnekleri olan bu sitelerde belli konular tek bir yerde yoğunlaşmaktadır. Son kategori olan Üniversite Sözlükleri başlangıçta okuldaki dersler, hocalar, sınavlar, ders geçeme sistemi gibi konularda paylaşılan yorumlardan oluşmasına rağmen sonrasında her konunun içeriğin paylaşıldığı sözlük sitelerine dönüşmüştür. Üniversite sözlükleri, yapı bakımından genel sözlükler kategorisine girmesine karşın çoğu üyesinin o okula bağlı olması nedeniyle ayrı bir kategoride listelenmektedirler (Bozkurt ve Biroğul, 2012, s.18).

Katılımcı sözlük sitelerinin ülkemizde ilk örneği Sedat Kapanoğlu tarafından, 15 Şubat 1999 tarihinde kurulan Ekşi Sözlük'tür (Akyazı 2014, s.188). Tüm dünyadaki internet trafiğini inceleyen ve internet siteleri hakkında raporlar oluşturan bir kuruluş olan Alexa'nın 2019 Şubat Ayı raporlarına göre Ekşi Sözlük ülkemizde en çok ziyaret edilen siteler arasında 11. sirada yer almaktadır (https://www.alexa.com/siteinfo/eksisozluk.com). Ekşi Sözlük'ün popüler bir mecra haline gelmesi ve zaman zaman üye alımlarını durdurmaya başlamıştır. Ekşi Sözlük'ün yazar alımını sınırlandırmasıyla, mevcut talebi değerlendirmek isteyen internet girişimcileri, Ekşi Sözlük'e alternatif olabilecek benzer projeleri hayata geçirmiştir. Bu tür girişimler "klon sözlük" adıyla anılmıştır (Öztekin, 2015, s.930). Klon sözlüklerin ilk başarılı örneği, İstanbul Teknik Üniversitesi öğrencileri tarafından hazırlanan ve Sedat Kapanoğlu'nun izniyle 2004'te yayın hayatına başlayan İTÜ Sözlük olmuştur (2015 yılı itibariyle adı İnstela olmuştur). İTÜ Sözlük'ü daha sonra 2005 yılında Uludağ Üniversitesi öğrencileri tarafından oluşturulan Uludağ Sözlük ve Aralık 2009'da İnci Sözlük kurulmuştur. Türkiye'de çok sayıda katılımcı sözlük siteleri bulunmaktadır ve bu sitelerin sayıları ger geçen gün de artmaktadır. 
Ekşi sözlügün kurucu Sedat Kaptanoğlu (2012) sitelerinde verilen bilginin doğru olması gibi bir zorunluluğun olmadığını, yanlış bilgi vermenin de gayet mümkün olduğunu belirtmektedir. Aynı zamanda Kaptanoğlu (2012) doğrunun otoritesinin okur olduğu savunmakta eğer okur yazılanlara değer biçiyorsa bunun okurun takdiri olduğunu ileri sürmektedir. 16 Aralık 2009'da kurulan İnci Sözlük'ün en eski yöneticisi Gürkan Dündar, planlı bir kuruluş olmadıkları, sansürcü zihniyetten bunalan birkaç internet kullanıcısının daha rahat olabileceği bir platform arayışıyla bir anda kurulduklarını ve ansiklopedik, tarafsız ve doğru bilgi içerme kaygısı yaşamadıklarını sadece eğlence amacı taşıdıklarını ifade etmiştir. Dündar, küfrü amaç değil, araç olarak gördüklerini ve küfrün yerinde kullanıldığı zaman Türkçe'yi güzelleştirdiğine inandı̆̆ 1 belirtmektedir. Popüler kültüre tepkili olduklarını belirten Dündar, yüzbinleri bulan kayıtlı kullanıcıları ile çeşitli eylemler organize ederek sisteme tepkileri her daim göstermeye çalıştıklarını ifade etmektedir (Bozkurt ve Biroğul, 2012, s.19-69).

Bu çerçevede inci sözlük 2011 genel seçimlerinde Eskişehir'den büfe işletmecisi Ahmet Yılmaz'ı sözlükteki yazarların maddi destekleri ile bağımsız milletvekili adayı göstermişlerdir (http://www.cnnturk.com). “Tanımlanmadık tek bir kelime kalmayana kadar" sloganıyla kurulan Uludağ Sözlük ülkemizde en fazla ziyaret edilen katılımcı sözlük siteleri arasında yer almaktadır. Uludağ sözlük moderatörlerinden Gökhan Gürleyendağ sözlüklerin öncelikle nicelikten çok nitelik kazanması gerektiğini belirtip bunun için daha fazla yazının değil daha kalıcı ve kaliteli bilgilerin sözlüğe aktarılmasının önemli olduğunu vurgulamakta ve yorum içeriklerinde argoya izin vermediklerini belirtmektedir. Gürleyendağ yorum içeriklerinde bariz doğru olmayan ve emin olunmayan bilgi içeren yazarların yazılarına müdahale ettiklerini ifade etmektedir. 2009 yılında "ötekileştirilen bir mahallenin sözcüsü olup sözün değerini yükseltme" misyonuyla kurulan bir başka katılımcı sözlük sitesi ise İHL sözlüktür. İHL sözlük sitesi yöneticilerinden Said Ercan kuruluş amaçlarının katılımcı sözlükler içinde ahlak temelli tematik sözlüklerin olmaması, kuralsızlığı kural olarak belirlemiş sözlüklere karşı belirli ahlaki temellere dayanan, argo, küfür, cinsellik ve hakaretin yer almadığı bir sözlük fikri olduğu belirtmiştir (2012 yılında internetteki faaliyetlerini durduran İHL Sözlük, sonra tekrar açllmış ve 2016 yılında İHL Sözlük'ün veri tabanı bir başka katılımcı sözlük sitesi 
olan Dünya Sözlük çatısı altında sunulmaya başlanmıştır). Bilgi Sözlük'ün kurucusu Bülent Cumhur Erol, siteyi 2004 yılında faaliyete geçirdiklerini, sitede yer alan tüm içeriklerin objektiflik taşıdığını fakat argonun Bilgi Sözlük'te yine yönetimin herhangi bir yerinde ve rahatsızlık vermeksizin kullanıldığını, Türkçe'nin özünde var olan argo kullanımının, herhangi bir şekilde yasaklanıp, kısıtlanmadığını belirtmektedir (Bozkurt ve Biroğul, 2012, s.19-69).

\section{Kullanıcı Profili ve Yazma Nedenleri}

Katılımcı sözlük siteleri yazarlarına ilişkin ayrıntılı bir profil bulunmamakla birlikte, ortak ilgi alanı internet olan ve öğrenci, medya çalışanı, akademisyen ağırlıklı bir kitle oldukları tahmin edilmektedir (Gürel ve Yakın, 2007, s.214). Katılımcı sözlük yazarlarının profiline ortaya koymaya yönelik en kapsamlı çalışmalardan biri Doğu vd. (2009) yaptıkları araştırmadır. Doğu vd., (2009) ülkemizin en popüler katılımcı sözlük sitesi olan Ekşi Sözlük'te yazarlık yapan kişilerin davranışlarını ve neden yazdıklarını belirlemek amacıyla yaptıkları araştırmada; yazarların günlük olarak ekşi sözlükte 1 ila 8 saat arasında zaman harcadıklarını belirlemiştir. Yazarların neredeyse hiçbiri yazar olarak wikiye katkıda bulunmamıştır. Kısa bir süre wikiler için yazanlar, Ekşi Sözlük'un yazarı olduklarında istifa etmişlerdir. Eksi Sözlük yazarlarına göre sitede yazar olmak prestijlidir, çünkü yazarların girdileri arama motorlarının sonuçlarında çıkmaktadır. Yazarlar sözlükte yanlış bilgi kadar, doğru bilginin de bulunabileceğini yönünde görüş bildirmişlerdir. Ayrıca yazarların çoğu, küfür kullanmaktan rahatsız olmadıklarını belirtmiştir. Yazarlar küfrün belirli bir kişiye yönlendirilmediği sürece küfür kullanmayı uygun bulmaktadır. Bir ekşi sözlük yazarı Ekşi Sözlük'un yazarı olduktan sonra hem sözlük platformunda hem de gerçek sosyal yaşamında küfür kullanmaya başladığını belirtmiştir. Eksi Sözlük platformunda, yazarların çoğu gerçek hayatta bildirilemeyecekleri konuları paylaştıklarını ifade etmişlerdir. Dolayısıyla Ekşi Sözlük, siber alandaki kullanıcı özelliklerinin gerekçelendirilmesinde önemli bir işleve sahip olduğu söylenebilir. Eksi Sözlük yazarları zaman zaman, bir mekânda toplanarak birbirleriyle tanıştıklarını ifade etmişlerdir. 
Ekşi Sözlüğün kurucusu Serdar Kaptanoğlu, Ekşi'nin yazar profilini, sözlükte her tür görüşün ve dahi küfrün serbest olmasından dolayı çoğunluğunu açık görüşlü insanların oluşturduğu 18-25 yaş aralığında kişilerden meydana geldiğini ifade etmiştir. Moderatörlük yapan kişileri de aklı başında ve makul insanlar şeklinde tanımlamıştır (Kaptanoğlu, 2011, s.363). Sine ve Özsoy (2017) 222 ekşi sözlük yazarının katılımıyla gerçekleştirdiği araştırmada, \%72'nin otuz yaş ve altında, \%50'den fazlasının lisans mezunu olduğunu belirlemiş ve akademisyen, öğretmen, doktor, ev hanımı, avukat, mühendis-mimar, gazeteci, serbest, memur, esnaf gibi çeşitli mesleklere mensup oldukları tespit edilmiştir.

Duman ve Özdoyran (2018) Türkiye'de yer alan katılımcı sözlük siteleri yazarları ile derinlemesine görüşme yaparak gerçekleştirdikleri araştırma sonucunda, yazarların tümünün lisans ve lisansüstü eğitim derecesine sahip olduğunu belirlemiştir. Katılımcı sözlük sitelerinde yazar konumunda olan kişilere göre sözlükler gündemi takip etmek, fikirlerini özgürce paylaşmak, sosyalleşmek, zaman geçirmek ve yazar olma hissini yaşamak için önemli bir alandır. Susar ve Narin $(2011$, s.3) katılımcı sözlük sitelerinin takipçilerini, 35 yaş altı, evden ve iş yerinden bağlanan, lisansüstü eğitimli, çocuksuz ve ağırlıklı olarak erkek kullanıcılardan oluştuğunu ifade etmektedir.

Uzunoğlu (2015) katılımcı sözlük siteleri yazar profili konusunda belirleyici tespitler yapmanın mümkün olmadığını belirtse de genel olarak katılımcı sözlük yazarlarının, yüksek eğitim sahibi, ă̆ırlıklı olarak beyaz yakalı bireylerden oluştuğunu ortaya belirtmiştir. Uçar (2006,s.40) katılımcı sözlük kullanıcılarının büyük çoğunluğu, üniversitede İngilizce eğitim görmüş veya görmekte olan genç nesil olduğunu belirtmiştir. Kat1lımcı sözlük sitelerinin dünyada fazla örneği bulunmamakla birlikte genellikle gençlerin oluşturduğu bu sözlüklerin aktardığı bilgi ve fikirlerin güvenirliliği ise her zaman tartışılmaktadır.

Katılımcı sözlük sitelerinin kurucuları da incelediğinde, genç girişimciler tarafından kurulduğu görüşmektedir. Haliyle gençler tarafından kurulmuş katılımcı sözlük sitelerini, büyük çoğunlukla gençlerin katıldığı internet sitesi olarak tanımlanabilir. Nitekim bu siteye reklam verenler işletmeler ve ürünleri de incelediğinde, reklam verilen ürünlerin daha çok gençlere hitap eden, gençlerin kullanabileceği ürünler olduğu görülmektedir (Lüküslü, 2011, s.51). 
Acıkoz ve Buber (2012), hepsi lisans düzeyinde eğitime sahip olan ekşisözlük'te yazarlık yapan ve düzenli olarak siteyi takip eden ziyaretçilerle yaptıkları görüşmede, insanların siteyi genellikle arama ve eğlence için kullandıklarını ortaya koymuştur. Acıkoz ve Buber (2012) yaptıkları görüşmede, katılımcıların hepsi sitedeki bilgilerin zayıf güvenilirliği konusunda hemfikir oldukların belirtmiş olmasına rağmen neredeyse tüm görüşmeciler siteyi, ikinci bilgi olarak kullandıklarını belirlemişlerdir. Katılımcılar eksisozluk'un araştırma aşamasında iyi öznel bilgi sağladığını ifade etmişlerdir. Bu nedenle kullanıcıların eksisozluk'ü daha ciddi bir araştırmaya başlamadan önce araştırmaya başlamak için iyi bir yer olduğunu düşündükleri belirlenmiştir.

Sine ve Özsoy (2017), kullanımlar ve doyumlar yaklaşımını temel alan ekşi sözlük yazarı üzerinde gerçekleştirdiği araştırmada, Ekşi Sözlük yazarlarının "bilgilenme" ana motivasyonu amacıyla yeni medyaya yöneldiğini belirlemiştir. Daha sonra yeni medya kullanımına yönelten ikinci önemli faktör ise "alışkanlık" ve sonra sırasıyla da medya kullanımında etkili olan diğer önemli üçüncü ve dördüncü faktörler ise sırasıyla, "sosyal etkileşim" ve "eğlenme ve rahatlama" faktörleri olduğu ortaya koymuşlardır. Üçer (2016), üniversite öğrencilerinin sosyal medyayı neden kullandığını Kullanımlar ve Doyumlar Yaklaşımı bağlamında değerlendiği araştırmada, üniversite öğrencilerinin Twitter'ı habere ulaşma ve düşüncelerini ifadesi etme amaçlı kullandıkları sonucuna ulaşmıştır.

Acıkoz ve Buber (2012), lisans düzeyinde eğitime sahip olup Ekşi Sözlük'te yazarlık yapan kişilerle yaptıkları görüşmede, bu kişilerin Ekşi Sözlük'te yazarlık yapmayı yüksek sosyal statü olarak gördüklerini ve bundan dolayı yazar olmaktan gurur duyduklarını belirlemiştir. Bu sonuçlara göre katılımcı sözlük sitelerinde yazar olmanın prestijli bir statü olarak algılandığı görülmektedir. Yazar olanın yüksek prestij algısı, katılımc1 sözlük sitelerinin popülaritesinin artmasının temel sebeplerinden biri olarak gösterilmektedir.

\section{Katılımcı Sözlük Sitelerine Yönelik Eleştirel Söylemler}

Katılımcı sözlük sitelerinde yazarlar, her konu hakkında yorumda bulunabilmekte, her konuda başlıklar açabilmektedir. Bu konuda en büyük 
eleştirilerden birini yazarların her konuda yorumda bulunabilmesi oluşturmaktadır. Sıklıkla eleştirilen bir başka konu ise bu tür sitelerde yazılanların doğru olması gibi bir gerekliliğinin olmaması konusudur. Bu tür sitelerde yer alan spekülatif bilgilerin rahatlıkla yayınlanabilmesi, katılımc1 sözlüklerini toplumu etkileyen manipülatif bilgilerin yer aldığ platformlar haline getirebilmektedir. İnternet platformlarından biri olan itiraf.com ve İstanbul.com kurucusu Ersan Özer, en popüler katılımcı sözlük sitelerinden biri olan ekşi sözlük için "Ekşi sözlüğün belli bir kitleyi gerçekten çok kötü eğittiğini ve yönlendirdiğini düşünüyorum. Hayatta hiçbir başarısı olmayanları çoğunlukta olduğu bir yer orası" şeklinde toplumu yanlış bilgilendirdiği ve yönlendirdiği konusunda eleştirmiştir (Özer, 2011,s.264-265). Gazneli (2005) katılımcı sözlük sitelerinden biri olan Ekşi Sözlük'te yapılan yorumları yeni linç aygıtı şeklinde tanımlayarak, girilen içerikleri eleştirmektedir. Öztekin (2015, s.926) katılımcı sözlük sitelerinde yazar olarak kabul edilen kişinin kişisel görüşü olarak son derece masum kabul edilen yorumların aslında yöneldiği kişi ya da grubu aşağılayabilmekte veya ötekileştirerek nefret suçuna hedef gösterebileceğine dikkat çekmektedir.

İçerikleri kullanıcılar tarafından oluşturulan katılımcı sözlük sitelerinde, yazarlarına görüşlerini özgürce ifade etme ve okurlarına farklı görüşlere aynı platformda ulaşabilme imkânı sağlamaktadır. Kavramlara yükledikleri anlamlar ve aktardıkları değerler nedeniyle bu sözlükler siber kültürün şekillenmesinde etkili platformlar haline gelmiştir. Ancak, katılımcı sözlükler de tıpkı internet gibi, toplumsal gruplara ilişkin nefret söyleminin sanal dünyada kolayca yayılabilmesine imkân sağlayabilmektedir. Sözlük yazarlarının takma isimler kullanarak gerçek kimliğini gizleyebilmesi, özgür ve alternatif bir kamusal tartışma platformu oluşturma potansiyeline sahip bu sözlükleri zaman zaman farklı toplumsal grupları ötekileştiren bir platforma dönüştürebilmektedir (Varol ve Tayanç, 2016, s.222).

Alp (2016) ekşi sözlük sitesinde çingenelerle ilgili oluşturulmuş içerikleri incelediği araştırmasında, çingenelere yönelik nefret söylemlerinin olduğunu belirlemiştir. Alp (2016) ekşi sözlükte çingenelere yönelik yapılmış açıklamaların \%55'nin olumsuz, \%21'ini olumlu, \%24'ünün ise nötr sıfatlara karşılık geldiği belirtmiş; Çingenelerle ilgili en çok çok olumsuz referansların ön plana çıtığını yorumlarda yüksek oranda hakaret ve küfür içerikli ifadeler kullanıldığını ortaya koymuştur. Alp (2016) paylaşılan 
yorumların dilini, sert, dışlayıcı ve ötekileştirici mahiyetinde olduğunu belirtmiş ve Ekşi Sözlük yazarlarının kullandıkları nefret söylemlerini tahammülsüzlüğün ve hoşgörüsüzlüğün dışavurumu olarak nitelendirmiştir.

Akyazı (2014) katılımcı sözlük sitelerinde kadınlar ve erkekler hakkında yazılan 2172 açıklamaya nefret söylemi açısından değerlendirildiği araştırmada, toplam girişler içinde nefret söyleminin \%16,5 oranında kaldığı̆, nefret söyleminin cinsiyet ayrımı gözetmediği sonucuna ulaşmıştır. Araştırmada nefret söylemi dile getirilirken cinsel içerikli sözcüklere \%24 oranında yer verildiği bir başka ifadeyle yaklaşık her dört nefret söyleminden birinin cinsel içerikli sözcük içerdiği belirlenmiştir.

Varol ve Tayanç (2016) katılımcı sözlük sitelerinde kadınlara ilişkin nasıl bir tutum sergilendiği, kadınların en sık hangi niteliklerle tanımlandığ 1 ve kadınlara karşı nefret söylemi kullanılıp kullanılmadığı tespit etmeye yönelik araştırmasında, kadınlara karşı cinsiyetçi bir söylemin hâkim olduğu, kadına yönelik pornografik betimlemeler üzerinden toplumun kolektif bilincinde kadın imgesinin cinsel nesne olarak kurulmasına katkıda bulunulduğu, dolayısıyla kadınların bir nefret söylemi içinde araçsallaştırıldığ1 tespit edilmiştir. Ancak kadınlara yönelik olumsuz tutum konusunda sözlükler arasında önemli farkların olduğu da belirlenmiştir. Bu tespitle birlikte, Varol ve Tayanç (2016) yaptıkları araştırmada, katılımcı sözlüklerin toplumsal cinsiyet eşitsizliğine karşı çıkan yeni ve alternatif bir tartışma platformu olmaktan ziyade, mevcut cinsiyetçi yapıyı koruyan ve pekiştiren bir tutum benimsediği sonucuna varmıştır.

Gürel ve Yakın'a (2007) göre katılımcı sözlük siteleri ile Chuck Palahniuk tarafından 1996 yılında yazılan 1999 yılında beyaz perdeye uyarlanan "Dövüş Kulübü" arasında paralellik kurulmuştur. Gürel ve Yakın (2007), Dövüş Kulübü üyeleri ‘Kundaklama Komitesi', 'Saldırı Komitesi', 'Tahribat Komitesi', 'Yanlış Bilgilendirme Komitesi' ve ‘Örgütlü Kaos Komitesi' gibi komitelerden oluşan 'Kargaşa Projesi' ile medeniyeti tasfiye ederek dünyayı daha iyi bir yer haline getirmeye çalıştıkları belirtmiş ve katılımcı sözlük sitelerinin de benzer bir işlev üstlendiğini ileri sürmüştür. $\mathrm{Bu}$ doğrultuda postmodern bir oluşum olarak değerlendirilebilen kat1lımcı sözlük siteleri, tüm katılımcıların konu kısıtlaması olmaksızın fikirleri özgürce belirtebildiği bir platform olmasının yanı sıra geleneksel varoluşa karşıt niteliğiyle de dikkat çekmektedir. 
Bu tür eleştirilere katılımcı sözlük sitelerini kuran yöneticiler de karşılık vererek katılımcı sözlük sitelerini savunmuşlardır. Ekşi Sözlüğün kurucusu Serdar Kaptanoğlu, ekşi sözlügün bilginin tek otoritesinin olamayacağı konusunda bir duruş sergilediği ifade ederek, sitede yer alan her bir maddenin altında "bu sitede yazllan hiçbir şey doğru değildir" şeklinde bir açıklama koyduklarını insanların her okuduğuna inanmamaları gerektiğini, doğru bilgi diye bir hazır paket olmadığını savunmaktadır. Serdar Kaptanoğlu, doğru bilgiye ancak sağlıklı bir eleştirel bakışla ulaşılabileceğini ifade etmektedir. Kaptanoğlu burada sağlıklı ve doğru bilgi edinilmesindeki en büyük sorumluluğu, bilgi isteyen kişiye yüklemektedir. Serdar Kaptanoğlu ekşisözlüğe yöneltilen en büyük eleştirinin, yazarların gerçek isimleri ile yazmamaları, müstear isimlerle yazdıkları eleştirisine katılmadığını şu sözleri ile açılamaktadır. "Ĕğer o verilen bilgi ancak kimin söylediğ $i$ ile değerliyse çok da mühim değildir zaten. Bilginin vereniyle değil sadece ve sadece kendisiyle değerli olduğunu idrak etme sürecindeyiz" söylemiyle verilen bilginin üzerinde durulması gerektiğine dikkat çekmiştir (Saka, 2010). IHL Sözlük'ün kurucularından olan Said Sercan, katılımcı sözlük sitelerini eleştiren kişileri, çağın gerisinde kalmış, çağı yakalayamamış, yeni oyun alanında geri kamışlığın kabusunu yaşayan kişiler olarak karşı eleştirisini yapmıştır. Aynı zamanda katılımcı sözlük sitelerine karşı olan kişileri, tarihte matbaaya karşı olan kişilere benzetmiştir (Saka, 2010). Fakat Said Sercan her ne kadar katılımcı sözlük sitelerini çağın bir aracı olduğunu dile getirse de, bu sitelerde çoğu zaman aklına gelen her şeyin düşünce süzgecinden geçirilmeden yazıldığını, sözlüklerin çok fazla yalan bilgi içerebildiğini, provokasyon için de kullanılabildiğini de ifade etmiştir (Sönmez, 2009).

Katılımcı sözlük sitelerinde aynı konu hakkında farklı ve birbirine zıt açıklama ve yorumların olmasının (Lüküslü, 2011,s.51; Telli 2011,s.52) bilgi kirliliği olarak eleştirenleri Lafmacun'un kurucularından olan Ahmet Uslu, bir katılımcı sözlük sitesinde aynı konu hakkında farklı yorumlar yapılmasını bilgi kirliliği olarak görmediğini ifade ederek, bir sözlük okuyucusunun herhangi bir konu hakkında pek çok subjektif ve objektif yoruma aynı anda ulaşabilmesini bilgi çeşitliliği olarak saydığını ifade etmiştir (Saka, 2010). İletişim alanında çalışan İstanbul Bilgi Üniversitesi öğretim üyesi Dr. Erkan Saka, Ekşi Sözlük yazarlarının ortaya koyduğu içe- 
riğin her türlü eleştirilmesine rağmen Türkiye'de bilgi üretimi ve paylaşımında bir dönüm noktası şeklinde açıklayarak, farklı bilgi paylaşımlarına ve çok sesliliğe dikkat çekmektedir (Saka, 2011,s.336).

Ekşi Sözlük ve diğer katılımcı sözlük siteleri yönetimleri, nefret söyleminin önüne geçebilmek adına bir denetim mekanizması geliştirmiştir. Gelen şikâyetler doğrultusunda nefret söylemi içeren başlık ve başlığa yazılan yorumlar (entry) silinmektedir. Ekşi Sözlük'ün nefret içeriklerini şikâyet yoluyla yayından kaldırması doğru bir uygulama olarak görülmektedir. Çünkü nefret söyleminin önüne geçmek adına paylaşılan içeriklerin yayından önce denetlenmesi ifade özgürlüğü açısından savunulamayacak bir uygulamadır. Fakat bu uygulamaya karşın Ekşi Sözlük'te nefret söyleminin önüne geçilememiştir. Her gün açılan başlık ve paylaşılan enrty sayısının çok oluşu, bazı nefret içerikli paylaşımların gözden kaçmasına neden olabilmektedir. Ayrıca denetim sistemi, tamamen kullanıcıların şikâyetleri doğrultusunda işlediği için kullanıcıların nefret söylemi konusunda farkındalıkları ve duyarlılıkları da önem kazanmaktadır. Oysa gündelik hayatta, politikada, okulda, kitaplarda, televizyonda, gazetelerde, sosyal medyada sürekli nefret söylemiyle karşılaşan, nefret söylemini kanıksayan ve bu konuda duyarsızlaşan bireylerin nefret söylemine karşı eleştirel bir tavır geliştirmelerini beklemek çok da anlamlı görünmemektedir. Bu yüzden her şeyden önce yeni medya ortamında da dolaşıma sokulan nefret söyleminin ortaya çıkış nedenlerinin ve koşullarının araştırılması; yeni medya kullanıcıları da dâhil herkese nefret söylemiyle ilgili farkındalık kazandırılması gerekmektedir (Öztekin, 2015, s.935).

Ekşi Sözlük'ün nefret söylemi konusunda geliştirdiği ve uygulamaya koyduğu özel bir denetim projesi bulunmaktadır. 2010 yılında başlatılan ve 2011 yılında uygulamaya konan Ekşi Sözlük Nefret Söylemi Denetim Projesi kapsamında Sözlük'te paylaşılan ve Ekşi Sözlük Nefret Söylemi Denetleme Yönetmeliği'ne göre nefret söylemi tanımına uyan başlık ve ifadeler, "Nefret Söylemi Denetim Grubu" tarafından incelenerek silinebilmekte; nefret söylemi içeren paylaşımı yapan yazarların üyelikleri silinebilmektedir. 19 Haziran 2011 tarihinde başlatılan uygulama, sözlük yazarlarından büyük tepki görmüş ve bir sansür mekanizması olarak değerlendirilmiştir. Diğer taraftan nefret söylemiyle mücadele kapsamında başlatılan projenin gerçek manada başarılı olduğunu söylemek pek mümkün 
değildir. Her ne kadar proje kapsamında nefret söyleminin tanımı yapılmışsa da hangi ifadelerin nefret söylemi kapsamında değerlendirilip hangilerinin değerlendirilemeyeceğinin nesnel ölçütlerinin olmaması, mücadeleyi zorlaştırmaktadır (Öztekin, 2015, s.931)

Sine ve Özsoy (2017), Ekşi Sözlük'ü, hayata dair önemli bilgileri ve ilginç detayları kullanıcılarla yani okur kitleyle paylaşan bir site olarak tanımlamaktadır. Sine ve Özsoy (2017), Ekşi Sözlük yazarlarının yaşamın içinden sıradan bireyler olmalarının yanı sıra bilgi paylaşımında samimi ve içten bir üslup kullanmalarının, resmi kaynakların tekdüze sunumuna alternatif olarak algılanmasını ve gerçeğin monotonluktan uzak bir içerikle sunumunu kolaylaştırdığı ifade etmektedir. Yazarlara göre, içeriği kullanıcılar tarafından oluşturulan sözlükte, veriler bilgilerin doğruluğu veya tarafsızlığ veya argo/olumsuz dil kullanımıyla ilgili bir denetim uygulanmaması, okuyucunun eğlenerek öğrenmesini ve her daim güncel bilgiye ulaştııılması mümkün kılınmaktadır. Sine ve Özsoy (2017), $(2017$,s.54) bu açıklamalar ışığında katılımcı sözlük sitelerini, çağcıl bir referans kaynağı olarak değerlendirmektedir. Gürel ve Yakın'a (2007,s.203204) göre, Ekşi Sözlük, doğru kavramının ne denli değişken olabileceğini ve doğruya pek çok farklı açıdan bakılabileceğini göstermektedir.

Varol ve Tayanç (2016, s.221) katılımcı sözlük sitelerini, özgür ve alternatif bir kamusal tartışma platformu oluşturma potansiyeline sahip bir platform olarak değerlendirmekte ve katılımcı sözlük sitelerinin, kavramlara yükledikleri anlamlar ve aktardıkları değerler nedeniyle siber kültürün şekillenmesinde etkili bir araç olduğunu ifade etmektedir. Doğu vd. (2009) katılımcı sözlük sitelerini, toplum içerisinde gerçek kimlikle ifade edilemeyen düşünce ve duyguların ifade edildiği bir platform olarak gördüklerini ve bu tür sitelerin kullanıcılarının fikirlerini gerçek hayattan daha iyi ve daha özgürce yansıtmalarını sağlayacaklarını savunmaktadır.

Uçkan (2012) katılımcı sözlük sitelerinin var olma amacını, internet-öncesi sözlükler ve ansiklopedilerin otoriter bilgi dağarcıkları tepki olarak kendi bilgi evrenini oluşturmak isteğinin tezahürü olarak açıklamaktadır. Uçkan'a (2012, s.24) göre katılımcı sözlükler aynı zamanda içinden çıktıkları toplumu en geniş çeşitliliği içinde yansıtan bir mikro kozmos gibi tanımlamakta ve orada derin muhalefetin de nefret söyleminin de, eleştiri- 
nin de hakaretin de bilginin de mizahın da var olduğunu ifade etmektedir. Uçkan (2012) bu durumu katılımcı sözlükleri kuralsız birer "Vahşi Batı" haline getirmediğini savunmaktadır.

Katılımcı sözlük siteleri, çok yazarlı kolektif olarak üretilen sanal bir platformdur. Bu sitelerde yer alan içerikler kolektif bir şekilde üretildiğinden dolayı, ilk bakışta çok sesli, demokratik ve özgürleştirici bir platform görüntüsü izlenimi vermektedir. Fakat her ne kadar bu sitelerde ortaklaşa bir içerik üretim potansiyeli olsa da, bunun tam olarak gerçekleşmediği görülmektedir. Katılımcı sözlük siteleri kendilerince bir otokontrol mekanizması oluşturarak, sözlük formatına uymayan yazarları, üyelikten çıarabildiği gibi sözlük formatına uymayan maddeler de sözlükten silinebilmektedir. Türkiye'de en fazla ziyaret edilen katılımcı sözlük sitelerinden biri olan ekşisözlük'ün 2006 yılı istatistiklerine göre, siteye girilen maddelerinin \%40'1 gözetiminden geçememiş veya yazarlar kendi beğenmedikleri maddeleri silmişlerdir. Bu yüksek silinme oranlarını Uçar (2006, s.41) masum ve formatsal bir öz-denetim mekanizmasından daha ötesine işaret ettiğine değinmektedir.

\section{Sonuç}

Time dergisi 2006 yılında "Yılın İnsanı"nı "Sen" olarak belirlemiştir. Bu uygulamadaki amaç; kullanıcı tabanlı içerik sonucu oluşan iletişim ile internet kullanıcılarının birbirlerini etkilemelerinin ne kadar önemli olduğunu vurgulamaktır. Kullanıcı tabanlı içerik insanların başka yerlerde ulaşamayacakları bilgilere ulaşmasını sağlamaktadır (İşlek, 2012, s.12). Günümüzde Web 2 olarak değerlendirilen katılımcı sözlük siteleri, hem bilgi toplanılan hem üyelerin bir birlerini takip ederek güncel olaylarla ilgili bilgilere, değerlendirmelere yer veren ve özellikle gençlerin zaman geçirdiği sosyal ağlar hâline gelmiştir. İnternet kullanıcıları arama motorlarında yaptıkları aramalarda katılımcı sözlük siteleri, içeriğinde birçok kavram ve açıklama barındırdığından dolayı ilk sıralarda çıkmaktadır. Haliyle katılımcı sözlük siteleri, herhangi bir bilgiye ulaşmak isteyen kişinin internet arama motorlarında karşısına çıkan ilk siteler arasında yer alabilmektedir. Düşünce ve görüşlerin yaklaşık 20 yıldır oluşturduğu bilgi birikim nedeniyle çoğu internet kullanıcısı katılımcı sözlükleri referans kaynağı olarak kullanmaktadır. 
Katılımcı sözlükleri her şeyin tartışılabildiği ve eleştirilebildiği bir ortam olmasının yanı sıra toplumsal bazda etkili olan pek çok tabu ve değerin sorgulanmasına aracılık ederek kendine özgü bir kültür oluşturmuştur (Duman ve Özdoyran, 2018, s.87-88). Aynı zamanda atılımcı sözlük siteleri, kavram, olay kişi gibi konular hakkında doğru, eksik veya yanlış fark etmeksizin içerik barındırması, okuyucuların algılarını, tutumlarını, düşünce yapılarını şekillendirebilmektedir. Bundan dolayı katılımcı sözlük siteleri eleştiren görüşler olduğu gibi destekleyen çeşitli görüşler de mevcuttur.

Günümüzde internet, özgür bir paylaşım alanı olarak kamusal tartışmaların yapıldığı önemli bir konu haline gelmiştir. İnternetin kamusal alan kavramında oluşturduğu dönüşüm bakımından iki görüş söz konusudur. İnternetin yaygınlaşmasına ve kullanımına liberal perspektiften bakan birinci görüş, internetin sağladığı olanaklara işaret etmektedir. Liberal yaklaşım, teknolojik gelişmeleri, kültürde ve toplumda demokratikleşmenin bir aracı olarak görür. Buna göre; her düzeyden kültürel ürün, düşünce ve fikir, tarihin hiçbir döneminde olmadığı kadar geniş bir yurttaş kitlesine ulaşabilir durumdadır. Liberal perspektiften bakan birinci görüş, demokratikleşme ile teknoloji arasında doğrudan bir ilişki kurarak, internete karşı olumlu bir tutum içerisindedir. İnterneti, bilgimizi parmaklarımızın ucundan tüm dünyaya ulaştırdığımız bir platform, zaman ve mekân mevhumunu ortadan kaldıran bir araç, bireylerin görüşlerini özgürce tartışabildikleri, gündem oluşturabildikleri, ötekilenen ve sistem d1şında bırakılan grupların seslerini duyurabildikleri bir mecra olarak görmektedir. İnternete eleştirel yaklaşan görüş Frankfurt Okulu ekolünden gelmektedir. Bu görüş interneti katılım imkânlarını arttıran bir araç olarak görmekten ziyade, hegemonik iktidar ilişkilerinin yeniden üretildiği bir yer olarak görmektedir. Çıkış noktasında ise, internet erişimindeki eşitsizlikler, internetteki bilgi enflasyonu ve manipülatif niteliğe vurgu yapılmaktadır (Armağan ve Deniz, 2012, s.75). Özetle olumlu görüş internetin demokratikleştirme ve özgürleşim potansiyellerine dikkat çekerek, onu bireylere sınırsız bir hareket olanağı sağlayan bir platform olarak görürken; olumsuz bakan görüş ise internetin olumluymuş gibi gözüken özelliklerini "tuzak" olarak niteleyerek; yeni iletişim teknolojilerini özgürlükleri kısıtlayan bir alan olarak görmektedir (Susar ve Narin, 2011, s.8). 
Katılımcı sözlük sitelerinin kamusal bir tartışma platformu niteliği taşıması nedeniyle, devamlı olarak tartışılmaktadır. Kimi çevrelerce ifade özgürlüğünün bir parçası ya da bir "iç dökme eylemi" olarak kabul ederek katılımcı sözlük sitelerini çok sesliliğin ve sessizliğin bir çığlığı olduğunu savunmakta; kimi çevreler de her konu ve kişi hakkında doğru olma zorunluğu barındırmayan görüşlerin aktarılmasıyla, kişi ve kurumlara yönelik hakaret ve nefret söylemlerinin paylaşıldığı bir platform olarak görmektedir.

İfade ve fikir hürriyeti insanın temel hak ve özgürleri arasındadır. Bir kişi ifade ve düşüncelerini, başka bir kişinin yaşam hakkı ve itibarını zedelemediği sürece dile getirilebilmeli, açıklayabilmelidir. Katılımcı sözlük sitelerinde konu kısıtlaması söz konusu olmaksızın, üye yazarlar görüşleri paylaşabilmektedir. Bu tür sitelerde yazarlar kendi görüşlerini ortaya koymakla birlikte, ortaya koyduğu görüşlerin doğru olma zorunluluğunun olmaması, rahatlıkla bir konu ya da kişi hakkında, okuyucuları yanlış bilgilendirebilmekte, manipüle edebilmektedir. Dijital katılımcı sözlükler her ne kadar paylaştıkça çoğalma mantığı ile çalışan web 2.0 temelinde çalışmaktadır. Haliyle bu tür sitelerde bir başlık altında yapılan doğru veya yanlış bir içerik insanları duygu, düşünce ve davranışlarını etkileme potansiyeline sahiptir. Bu çerçeve katılımcı sözlük siteleri, bir yandan düşünce ve fikir hürriyetini kısıtlamadan bir yandan da kasıtlı olarak yanlış ve doğru olmayan, nefret söylemlerini barındırmayan bir denetim mekanizmaları kurması, bu tür siteleri sağlıklı ve doğru bir bilgi kanalı haline getirecek ve böylece katılımcı sözlük siteleri toplumsal hoşgörüye ve de entelektüel derinliğe muazzam katkılar sağlayacaktır. 


\title{
EXTENDED ABSTRACT
}

\section{A Review of Collaborative Hypertext Dictionary as a New Media Communication Channel}

\author{
* \\ Engin Üngören \\ Alaaddin Keykubat University
}

Since the beginning of the 2000s, the development of hardware, software and technical network infrastructure has led to the emergence of a new paradigm in the internet. Web 2.0 or new generation websites, which are called social media in recent years, have turned into a medium where the user can upload photos, videos, music, make comments, share his experiences with others, in other words directly affect the content of the site. Godin (2004) emphasizes the locomotive power of the internet in the spread of ideas like a virus by saying that there will be people in the future who are saying and spreading their ideas. Before the internet, an idea spreads in a limited area and from one source, and today the ideas that are renewed, changed and re-organized as they spread through the mouth and renewed as it spreads by means of user-based content, lead to the emergence of more qualified information (İşlek, 2012, p.12-13).

As can be understood from these explanations, one of the most important functions of the internet is the data transfer tool. In other words, information transmission is manifested in many different sizes through the internet.

Transfer of information through the internet shows itself in very different dimensions. It has been able to reach unlimited information through search engines. In addition, the internet has had a significant impact on communication. By ignoring the concepts of time and space, the Internet has made mutual communication possible with individuals in far-away geographies. In our country, there are sites that transfer information in different ways. Among the most important ones, and among the most visited web pages in our country, collaborative hypertext dictionary sites are formed (Yıldırım \& Başer, 2016, p.174-180). 
Collaborative hypertext dictionary sites are accepted as one of the first examples of web 2.0 period and social media (Susar and Narin, 2011, p.3). The Collaborative hypertext dictionary sites are a web 2.0 project inspired by the dictionary and based on interaction. The collaborative hypertext dictionary sites appear as an entity that transfers information in different ways. In the the collaborative hypertext dictionary, members write comments about various concepts. In these types of formations, the author is called as a contributing writer by writing to each member. The authors who are members of the participant dictionaries can comment on and explain the concept, the event and the people. And other users commenting on these topics and creating a very wide content structure. In a sense, these dictionaries have changed the quality of the internet forums. The differences of the dictionaries from the internet forums are that the forums contain restricted topics specific to a specific topic. On collaborative hypertext dictionary sites, there is no restriction on a topic. The collaborative hypertext dictionary include objective information as well as subjective information and opinions. Although authors present their views on collaborative hypertext dictionary sites, their views do not have to be correct. From this point of view, collaborative hypertext dictionary sites differ from internet encyclopedias because they do not have to include linear information. As a matter of fact, there is a wide variety of information about a subject in the collaborative hypertext dictionaries. This information may be objective and accurate, as well as manipulative, and may include negative thoughts about the subject (Yıldırım \& Başer, 2016, p.186; Akkılıç, 2018, p.19; Lüküslü, 2011,p.52).

The first example of collaborative hypertext dictionary sites in Turkey is sour dictionary founded by Sedat kapaloğlu in February 1999 (Akyazı 2014, p.188). After the sour dictionary was founded, many different participating dictionary sites were established by cloning the sour dictionary format exactly. The collaborative hypertext dictionary sites, which have always been popular since they were founded and which reach the maximum number of visitors in our country on a daily basis, draw attention to the fact that they allow people to interpret everything about the issue. The collaborative hypertext dictionary sites, which are a virtual formation that mediates the interrogation of patterns about the truth and which operate 
on a self-organized basis, are important in terms of defining a form of communication specific to the contemporary world and creating public opinion in the society (Sine \& Özsoy, 2017, p.54). As stated by Armağan and Deniz (2012), many politicians, artists, media members and academics can take the basis of collaborative hypertext dictionary sites in order to determine the direction of public opinion on controversial issues.

The increasing popularity of the collaborative hypertext dictionary has begun to make it an important subject of academic research. In the last two decades, collaborative hypertext dictionaries have been the focus of interest in academic studies. The studies on the collaborative hypertext dictionary are generally prone to discourse and content (Duman and Özdoyran, 2018, p.84). The main rationale for the study of collaborative hypertext dictionary sites is that such sites become an important channel for public opinion creation and information.

In 2006, Time magazine identified the people of the year as "YOU". The purpose of this application is to emphasize the importance of communication between user-based content and the impact of internet users on each other. User-based content allows people to access information that they cannot reach elsewhere (İşlek, 2012, p.12). Today, collaborative hypertext dictionary sites, which are considered as web 2, have become social networks where young people spend their time by following each other and keeping up to date information about the events and evaluations. The collaborative hypertext dictionary sites in the searches made by internet users in the search engines, are at the top of the list because they contain many concepts and explanations. As a result, the collaborative hypertext dictionary sites can be among the first sites that appear in the internet search engines of the person who wants to reach any information. Due to the accumulation of knowledge and opinions about 20 years, most internet users use collaborative hypertext dictionaries as reference source (Duman \& Özdoyran, 2018, p.88).

In addition to being an environment where everything can be discussed and criticized, the collaborative hypertext dictionaries have created a unique culture by mediating the questioning of many taboos and values that are effective on a social basis (Duman \& Özdoyran, 2018, p.87). At the same time collaborative hypertext dictionaries, it is possible to shape readers' perceptions, attitudes and thought structures about concepts, event 
and peope content hosting regardless of whether it is true, incomplete or false. Therefore, there are various opinions that support the collaborative hypertext dictionaries sites as well as criticizing.

As the collaborative hypertext dictionary sites are a public discussion platform, they are constantly discussed. In some circles, the collaborative hypertext dictionaries are regarded as part of freedom of expression or as an "internal act". This section argues that such websites are a cry of polyphony and silence. Some other circles see the collaborative hypertext dictionary sites as a platform for sharing insulting and hate speech to individuals and institutions because of the transmission of opinions that do not have the right to be true about each subject and person.

Freedom of expression and of thought are among the fundamental rights and freedoms of man. A person should be able to express his / her expression and thoughts, unless it damages another person's right to life and reputation. Member authors can share opinions without subject limitation on collaborative hypertext dictionary sites. Although the authors present their own opinions on such sites, the lack of the necessity of being correct is that they can easily inform and manipulate readers about a subject or a person. The digital collaborative hypertext dictionary sites work on the basis of Web 2.0, which works with the logic of duplicating as they share dictionaries. As such, right or wrong content on such sites under a title has the potential to affect people's feelings, thoughts and behavior. This framework of the collaborative hypertext dictionary sites should establish a control mechanism that does not contain intentional misconceptions and hate speech without restricting the freedom of thought and ideas. Such an application will make such sites a healthy and accurate information channel. Thus, the collaborative hypertext dictionary sites will provide enormous contributions to social tolerance and intellectual depth.

\section{Kaynakça / Reference}

Açıöz, T. ve Büber, H. (2012). Eksisozluk as a learning platform, Spring 2012 Independent Study Final Report School of Information Sciences University of Pittsburgh. http://www.pitt.edu/ peterb/indepstudies/2970-AcikozBuber-122.pdf adresinden erişildi. Erişim Tarihi: 02 Nisan 2019 
Akkılıç, S. (2018). Bir ötekileştirme mecrasi olarak sosyal medya: Ekşi sözlük ve ermeniler, Yüksek Lisans Tezi, Hacettepe Üniversitesi Sosyal Bilimler Enstitüsü, Ankara.

Akyazı, A. (2014). Yeni iletişim ortamı olarak dijital katılımcı sözlüklerde nefret söylemi, Marmara İletişim Dergisi, 22, 183-193.

Alp, H. (2016). Çingenelere yönelik nefret söyleminin Ekşi Sözlük'te yeniden üretilmesi, Ankara Üniversitesi İLEF Dergisi, 3(2), 143-172.

Armağan, A. ve Deniz, Ş. (2012). Çocuk istismarının sosyal paylaşım platformlarında temsil biçimleri: Pozantı cezaevinde kalan çocuklar örneğinin ekşi sözlük'te sunumu, International Journal of Social Science, 5(7), 69-88.

Atıcı, B. ve Yıldırım, S. (2010). Web 2.0 uygulamalarının e-öğrenmeye etkisi, Akademik Bilişim'10, XII. Akademik Bilişim Konferansı Bildirileri Kitabı içinde (287-292.), 10 - 12 Şubat 2010 , Muğla Üniversitesi.

Barsky, E. (2006). Introducing web 2.0: Weblogs and podcasting for health librarians, Journal of the Canadian Health Librarians Association, 27 (2), 33-34.

Barsky, E. ve Purdon, M. (2006). Introducing web 2.0: Social networking and social bookmarking for health librarians, Journal of the Canadian Health Libraries Association, 27(3), 65-67.

Beldarrain, Y. (2006). Distance education trends: integrating new technologies to foster student interaction and collaboration, Distance Education, 27(2), 139-153.

Bozkurt A. ve Biroğul S. (2012). Bilgiyi kümülatif bir biçimde oluşturup paylaşan siteler: Etkileşimli sözlükler, Bilişim Dergisi, 6(140), 16-69.

Constantinides, E. ve Fountain, S.J. (2008). Web 2.0: Conceptual foundations and marketing issue. Journal of Direct, Data and Digital Marketing Practice, 9, 231-244.

Doğu, B., Zıraman, Z. ve Zıraman, D. E. (2009), Web based authorship in the context of user generated content, an analysis of a Turkish web site: Eksi sozluk, (in The Real and The Virtual), Daniel Riha ve Anna Maj (Eds.), Oxford: Inter-Disciplinary Press.

Duman, K. ve Özdoyran, G. (2018). Dijital Emek ve Kullanıcı İçeriğinin Metalaşması: Katılımcı Sözlük Yazarları Üzerine İnceleme, Erciyes İletişim Dergisi, 5(4), 75-99. 
Erdem, R. ve Bardak, N. (2010). Türkiye'deki yönetim ve organizasyon otoritelerinin 'Ekşi Sözlük' perspektifi ile incelenmesi, Sosyal Ve Beşeri Bilimler Dergisi, 2(2),105-110.

Gazneli, F. (2005, Mayıs). Ekşi Sözlük'ü nereye koymalı? Eski Edebiyat ve Düşün Dergisi, 43, 63-64.

Godin, S. (2004). Fikir virüsü: Pazarlamada yeni boyutlar.(E. Özsayar, Çev.) İstanbul: Rota Yayınları

Gürel, E. ve Yakın, M. ( 2007). Ekşi Sözlük: postmodern elektronik kültür, Selçuk Üniversitesi İletişim Fakültesi Dergisi, 4(4), 202-220.

İşlek, M. (2012). Sosyal medyanın tüketici davranışlarına etkileri: Türkiye'deki sosyal medya kullanıcıları üzerine bir araştırma, Yüksek Lisans Tezi, Karamanoğlu Mehmetbey Üniversitesi Sosyal Bilimler Enstitüsü, Karaman.

Jackson, N. ve Lilleker, D. (2009). Building an architecture of participation? political parties and web 2.0 in Britain, Journal of Information Technology \& Politics, 6, 232-250.

Kaptanoğlu, S. (2011). Röportaj, Aydemir, AT (Der.) içinde, Katılımın EHali: Gençlerin Sanal Alemi, İstanbul: Alternatif Bilişim Derneği.

Küçükcan, T. (2005). Dinî yayıncılıkta internet (Sanal Dinî Iletişim Açısından Yeni Alanlar Ve Yeni Stratejiler), II. Uluslararası Dinî Yayınlar Kongresi, Sesli - Görüntülü Dinî Yayıncılık, Ankara.

Kutlutürk, L. ve Akbayrak, E.H. (2013). Akademik araştırmalarda web 2.0 etkisi: ODTÜ ve Mendeley işbirliği, ÜNAK 2013 Konferansı: Bilgi Sistemleri, Platformlar, Mimariler ve Teknolojiler, İstanbul.

Lüküslü, D. (2011). Bilişim Teknolojileriyle Örgütlenen Gençlik Hareketleri ve Yeni Bir Siyaset Arayışı, A.T. Aydemir (der.) içinde. Katılımın e-hali: gençlerin sanal alemi, İstanbul: Alternatif Bilişim Derneği.

Murugesan, S. (2007). Understanding Web 2.0, IEEE IT Pro., Web Technologies. July-August, 34-42.

Özbolat, A. (2013). İhlsözlük'te dindar gençliğin özneleşmesi: İmam hatipli, ahlaklı ve entelektüel, Birey ve Toplum, 3(6), 51-72.

Özer, E. (2011). Röportaj, A.T. Aydemir (der.) içinde. Katılımın e-hali: gençlerin sanal alemi, İstanbul: Alternatif Bilişim Derneği.

Öztekin, H. (2015). Yeni medyada nefret söylemi: Ekşi Sözlük örneği, Uluslararası Sosyal Araştırmalar Dergisi, 8(38), 925-936. 
Saka, E. (2011). Blogging ve gençliğin internet üzerinden katılım süreçleri üzerine bir deneme, Aydemir, AT (der.) içinde. Katılımın E-Hali: Gençlerin Sanal Alemi, İstanbul: Alternatif Bilişim Derneği.

Saka, H. (2010). Ne kadar bilgisayar o kadar yazar, Yeni Şafak Gazetesi Kitap Eki, 10 Mart 2010.

Sigala, M. (2009). E-service quality and web 2.0: Expanding quality models to include customer participation and inter-customer support, The Service Industries Journal, 29(10), 1341-1358.

Sine, R. ve Özsoy, S. (2017). Ekşi Sözlük kullanıcılarının yeni medya Kullanim Pratikleri, Route Educational and Social Science Journal, $4(8), 53-65$.

Sönmez, Z. (2009). Internette Sözlük Furyası, 31 Mart 2019 tarihinde, http://www.on5yirmi5.com adresinden erişildi.

Susar, F. ve Narin, B. (2011). Sosyal paylaşımın tecimselleştirilmesi bağlamında internet reklamcılığı: Ekşi Sözlük örneği, İstanbul Arel Üniversitesi İletişim Fakültesi İletişim Çalışmaları Dergisi, 3, 1-14.

Taşdemir,B. ve Çelik, R. (2013). Hâkim tasarım ve Ekşi Sözlük: İnternet'in dönüşümünü anlamak, İletişim Kuram ve Araştırma Dergisi, 37, 2239.

Telli, A.A. (2011), Katılımın e-hali: Gençlerin sanal alemi, Kasım, İstanbul: Alternatif Bilişim.

Uçar, A. (2006). Ekşi Sözlük: Format sözlükçüleri gözetliyor, Millî Folklor, 18(71), 39-43.

Üçer, N. (2016). Kullanımlar ve doyumlar yaklaşımı bağlamında gençlerin sosyal media kullanımına yönelik niteliksel bir araştırma, Global Media Journal, 6 (12), 1-26.

Uçkan, Ö. (2012). Sözlükler: Türkiye internet kültürünün vazgeçilmezi, Bilişim Dergisi, 140(12), 21-27.

Uzunoğlu, S. (2015). Bir postmodern intiharın ardından Ekşi Sözlük'te kanaatlerin oluşumu ve grupların biçimlenme süreçleri, Intermedia International Peer-Reviewed E-Journal Of Communication Sciences, 2(2), 424-439.

Varol, S.F. ve Tayanç, N.K. (2016). Yeni medya- eski dil: Katılımcı internet sözlüklerinde cinsiyetçi söylem, The Journal of Academic Social Science Studies, 46(4), 221-232. 
Yalçın, N. (2015). Sosyal medyada simgesel şiddet: Ekşi Sözlük örneği, Yüksek Lisans Tezi, Pamukkale Üniversitesi Sosyal Bilimler Enstitüsü Genel Sosyoloji Ve Metodoloji Anabilim Dalı, Denizli.

Yıldırım, O. ve Başer E. (2016). İnternetin girişimciliği kapsamında değişen enformasyon siteleri üzerine bir değerlendirme, Global Media Journal , 6(12), 172-200.

http://www.alexa.com/topsites/countries/TR, Erişim Tarihi: 04 Nisan 2019 http://www.cnnturk.com/2011/yasam/diger/06/15/inci.sozluk.ahmet.abiye.seslendi/620108.0/, Erişim Tarihi: 02 Nisan 2019.

\section{Kaynakça Bilgisi / Citation Information}

Üngören, E. (2019). Yeni medya iletişim kanalı olarak katılımcı sözlük sitelerine yönelik bir değerlendirme. OPUS-Uluslararası Toplum Araştırmaları Dergisi,11(18), 2878-2907. DOI: 10.26466/opus.567125 